\title{
Durerea abdominală recurentă sau cronică de cauză digestivă - ce ne este util în diagnostic?
}

\author{
Daniela Pop 1 , Sofia Psarrou², Dorin Farcău3,4 \\ ${ }^{1}$ Disciplina Pediatrie III, Universitatea de Medicină și Farmacie „Iuliu Hațieganu“, Cluj-Napoca, România \\ ${ }^{2}$ Medical School, University of Crete, Grecia \\ ${ }^{3}$ Clinica Pediatrie III, Spitalul Clinic de Urgență pentru Copii, Cluj-Napoca, România \\ ${ }^{4}$ Disciplina Nursing, Universitatea de Medicină și Farmacie „Iuliu Hațieganu“, Cluj-Napoca, România
}

\begin{abstract}
REZUMAT
Scopul acestui studiu a fost să aflăm care sunt cele mai frecvente afecţiuni digestive care sunt diagnosticate în secţia noastră pornind de la durerea abdominală recurentă sau cronică şi să evaluăm utilitatea investigaţiilor efectuate în scop diagnostic.

Material şi metodă. Au fost luaţi în studiu copiii care s-au prezentat în clinica noastră pe parcursul unui an, ianuarie 2019-decembrie 2019, pentru durere abdominală cronică sau recurentă şi care au fost diagnosticaţi cu afecţiuni organice sau funcţionale digestive. A fost un studiu retrospectiv, descriptiv. Lotul de studiu a inclus 86 copii, cu vârste cuprinse între 2 şi 18 ani, media vârstei \pm deviaţia standard (DS) $=10,4 \pm 3,8$ ani, 49 fete (57\%).

Rezultate. 29 dintre pacienţi (34\%) au fost diagnosticaţi cu afecţiuni organice şi 57 (66\%) cu afecţiuni funcţionale digestive. Simptome sau semne de alarmă au fost prezente la $16 / 29$ pacienţi (55\%) diagnosticaţi cu afecţiuni digestive organice şi 14/57 (37\%) dintre cei cu tulburări funcţionale gastrointestinale. Gastrita şi gastroduodenita, respectiv boala de reflux gastroesofagian au fost cele mai frecvent diagnosticate afecţiuni organice, în 16\%, respectiv $14 \%$ din cazuri, iar dintre tulburările funcţionale gastrointestinale, durerea abdominală funcţională nespecificată $(23 \%)$ şi dispepsia funcţională (20\%). Ecografia abdominală a fost efectuată la $80 \%$ dintre pacienţi, însă a permis stabilirea cauzei durerii abdominale cronice/recurente în doar $7 \%$ dintre aceste cazuri. Anticorpii antitransglutaminaza tisulară (IgA) şi calprotectina fecală au fost determinate într-un număr mic de cazuri (7\%, respectiv $6 \%)$.

Concluzii. Caracteristicile clinice ale durerii abdominale şi asocierea semnelor sau simptomelor de alarmă nu sunt suficiente pentru a diferenţia o patologie organică digestivă de una funcţională. Multe dintre investigaţiile paraclinice efectuate la pacienţii cu dureri abdominale recurente/cronice de cauză digestivă nu sunt utile pentru stabilirea cauzei durerii abdominale.
\end{abstract}

Cuvinte cheie: durere abdominală, copii, cauze, tract digestiv

\begin{abstract}
Abrevieri
DS - deviaţia standard

VSH - viteza de sedimentare a hematiilor

PCR - proteina C reactivă
\end{abstract}

\section{INTRODUCERE}

În 1957, John Apley a definit durerea abdominală recurentă ca cel puţin 3 episoade de durere care apar în ultimele 3 luni şi care sunt suficient de intense pentru a interfera cu activitatea zilnică (1). Durerea abdominală recurentă, descrisă de Apley, afecta aproxi- mativ 10\% dintre copiii de vârstă şcolară (1). Cauzele durerii abdominale sunt numeroase, digestive sau extradigestive, iar cele digestive pot să intre în categoria afecţiunilor organice, de motilitate sau funcţionale (2-4). Mai mult, se discută din ce în ce mai des despre asocierea unei tulburări funcţionale digestive manifestată prin dureri abdominale chiar şi la pacien- 
ţii la care este diagnosticată o afecţiune organică (5-7). O posibilă explicaţie ar fi faptul că patologia organică predispune la hipersensibilitate viscerală, ducând la declaşarea simptomelor afecţiunilor funcţionale gastrointestinale (8).

Caracteristicile durerii abdominale (localizare, durată, intensitate, recurenţă, apariţia în timpul zilei sau a nopţii, asociarea cu alte simptome, legătura cu alimentaţia sau defecaţia şi factorii care declanşează, accentuează sau ameliorează durerea) sunt dificil de cuantificat la copii, mai ales la vârstele mici. Durerea abdominală cronică sau recurentă reprezintă o cauză frecventă de prezentare la medicul de familie, pediatru sau specialistul în gastroenterologie pediatrică (9). Pe de altă parte, mulţi pacienţi se prezintă în departamentele de urgenţă în mod repetat $(10,11)$. Smith şi colaboratorii raportează că 5-10\% dintre vizitele în departamentele de urgenţă sunt pentru dureri abdominale (10).

Etapele parcurse în diagnosticul unui pacient care se prezintă pentru dureri abdominale recurente/cronice pornesc de la colectarea datelor clinice prin anamneză şi examen obiectiv, cu o atenţie specială la simptomele şi semnele „de alarmă“ care ar putea să sugereze o patologie organică. În funcţie de aceste date, vor fi indicate investigaţii paraclinice menite să confirme sau să excludă o afecţiune care are un substrat anatomic, biochimic sau inflamator. Dacă acest substrat nu este dovedit, algoritmul diagnostic se îndreaptă către tulburările funcționale gastrointestinale, clasificate azi în funcţie de datele clinice în clasificarea Roma IV $(12,13)$, în secţiunile dedicate patologiei pediatrice, la diferite categorii de vârstă.

Prevalenţa durerii abdominale funcţionale este de aproximativ 13,5\% (9). Ea este mai frecventă la sexul feminin şi este asociată cu tulburări psihologice şi evenimente cu impact emoţional $(14,15)$.

În cazul tulburărilor funcţionale gastrointestinale, substratul fiziopatologic al durerii abdominale nu este cunoscut. Alterarea microbiotei intestinale, hipersensibilitatea viscerală, alterarea interacţiunii dintre sistemul nervos enteral şi sistemul nervos central, factori psihosociali, activarea sistemului imun au fost propuse ca posibile explicaţii pentru simptomele acestei categorii de afecţiuni (16).

Scopul acestui studiu a fost să aflăm care sunt cele mai frecvente afecţiuni digestive care sunt diagnosticate pornind de la durerea abdominală recurentă sau cronică şi să evaluăm utilitatea investigaţiilor efectuate în scop diagnostic.

\section{MATERIAL ŞI METODĂ}

$\mathrm{Au}$ fost luaţi în studiu copiii care s-au prezentat în clinica noastră pe parcursul unui an, ianuarie 2019- decembrie 2019, pentru durere abdominală cronică sau recurentă şi care au fost diagnosticaţi cu afecţiuni organice sau funcţionale digestive. A fost un studiu retrospectiv, descriptiv.

Lotul de studiu a inclus 86 copii, cu vârste cuprinse între 2 şi 18 ani, media vârstei \pm deviaţia standard $(D S)=10,4 \pm 3,8$ ani, 49 fete $(57 \%)$. Au fost colectate datele clinice (durata durerii abdominale, localizarea, intensitatea, factori care agravează sau ameliorează durerea abdominală, legătura cu alimentaţia sau cu defecaţia, alte semne sau simptome asociate, modificări la examenul obiectiv) şi paraclinice ale acestor pacienţi, respectiv diagnosticul final din foile de observaţie.

$\mathrm{Au}$ fost excluşi din studiu copiii care au avut alte afecţiuni decât cele digestive manifestate prin dureri abdominale cronice sau recurente. De asemenea, au fost excluşi din studiu copiii cu afecţiuni cronice neurologice, psihiatrice, cardiace, respiratorii.

Prelucrarea datelor clinice şi paraclinice s-a efectuat prin crearea unei baze de date utilizând Microsoft 365 Excel 2010. Pentru pentru analiza statistică s-au folosit măsurători ale tendinţei centrale (media), variabilităţii (DS) şi procentuale.

\section{REZULTATE}

\section{Caracteristici clinice ale durerii abdominale}

Durerea abdominală recurentă sau cronică de cauză digestivă a fost motivul prezentării la 8 pacienţi cu vârste sub 5 ani $(9,3 \%), 25$ pacienţi $(29,1 \%)$ cu vârste cuprinse între 5 şi 9 ani, 28 copii $(32,5 \%)$ cu vârste între 9 şi 13 ani şi 25 pacienţi $(29,1 \%)$ cu vârste peste 13 ani. Patologia organică a fost cauza durerii abdominale la $15 / 29$ copii $(52 \%)$ cu vârste peste 13 ani, iar patologia funcţională a fost diagnosticată la 23/57 copii $(40 \%)$ cu vârste cuprinse între 5 şi 9 ani şi la 17/57 (30\%) copii cu vârste cuprinse între 9 şi 13 ani.

Durata afecţiunii, localizarea durerii abdominale respectiv frecvenţa şi durata episoadelor de durere abdominală sunt redate în Tabelul 1.

\section{Semne şi simptome „de alarmă“}

29 dintre pacienţi (34\%) au fost diagnosticaţi cu afecţiuni organice şi 57 (66\%) cu afecţiuni funcţionale digestive. Simptome sau semne de alarmă au fost prezente la 16/29 pacienţi (55\%) diagnosticaţi cu afecţiuni digestive organice. În Tabelul 2 sunt redate aceste simptome/semne de alarmă şi numărul copiilor la care au fost descrise. Dintre copiii cu diagnostic final de tulburare funcţională gastrointestinală, 14/57 (37\%) asociau semne/simptome de alarmă. 
TABEL 1. Caracteristicile durerii abdominale recurente/cronice la pacienții din lotul de studiu

\begin{tabular}{|c|c|c|c|c|c|c|}
\hline Durata simptomelor & 2-5 luni & 6-12 luni & $\geq 12$ luni & $\geq 2$ ani & & \\
\hline Număr total copii (\% & $42(49 \%)$ & $19(22 \%)$ & $7(8 \%)$ & $18(21 \%)$ & & \\
\hline $\begin{array}{l}\text { Număr copii cu patologie } \\
\text { organică/funcțională }\end{array}$ & $11 / 31$ & $7 / 11$ & $3 / 4$ & $7 / 11$ & & \\
\hline Frecvența episoadelor & Zilnic & 4-6 ori/săptămână & 1-3 ori/săptămână & 1-3 ori/lună & & \\
\hline Număr total copii (\%) & $49(57 \%)$ & $6(7 \%)$ & $25(29 \%)$ & $6(7 \%)$ & & \\
\hline $\begin{array}{l}\text { Număr copii cu patologie } \\
\text { organică/funcțională }\end{array}$ & $18 / 31$ & $3 / 2$ & $6 / 19$ & $1 / 3$ & & \\
\hline Durata episoadelor de durere & 1-15 minute & $15-30$ minute & $30-60$ minute & $\geq 60$ minute & $\geq 120$ minute & \\
\hline Număr total copii (\%) & $10(12 \%)$ & $18(21 \%)$ & $29(34 \%)$ & $22(25 \%)$ & $7(8 \%)$ & \\
\hline $\begin{array}{l}\text { Număr copii cu patologie } \\
\text { organică/funcțională }\end{array}$ & $1 / 8$ & $6 / 12$ & $12 / 17$ & $2 / 19$ & $5 / 1$ & \\
\hline Localizarea durerii abdominale & Periombilical & Epigastric & $\begin{array}{l}\text { Hipocondrul } \\
\text { stâng }\end{array}$ & $\begin{array}{c}\text { Hipocondrul } \\
\text { drept } \\
\end{array}$ & $\begin{array}{c}\text { Flancul } \\
\text { stâng }\end{array}$ & $\begin{array}{r}\text { Flancul } \\
\text { drept }\end{array}$ \\
\hline Număr total copii (\%) & $45(52 \%)$ & $42(49 \%)$ & 3 & 1 & $5(6 \%)$ & $5(6 \%)$ \\
\hline $\begin{array}{l}\text { Număr copii cu patologie } \\
\text { organică/funcțională }\end{array}$ & $6 / 39$ & $24 / 18$ & $3 / 0$ & $0 / 1$ & $3 / 2$ & $0 / 1$ \\
\hline
\end{tabular}

TABEL 2. Simptome şi semne „de alarmă“

\begin{tabular}{|l|c|c|c|c|c|}
\hline Semn/simptom & $\begin{array}{c}\text { Hemoragie digestivă } \\
\text { inferioară }\end{array}$ & $\begin{array}{c}\text { Vărsături } \\
\text { peristente }\end{array}$ & $\begin{array}{c}\text { Scădere involuntară } \\
\text { în greutate }\end{array}$ & $\begin{array}{c}\text { Retard al } \\
\text { creşterii }\end{array}$ & $\begin{array}{c}\text { Diaree } \\
\text { nocturnă }\end{array}$ \\
\hline $\begin{array}{l}\text { Număr de copii din lotul } \\
\text { de studiu }\end{array}$ & 2 & 8 & 4 & 9 & 7 \\
\hline $\begin{array}{l}\text { Număr de copii } \\
\text { diagnosticați cu afecțiuni } \\
\text { organice }\end{array}$ & 1 & 6 & 2 & 5 & 2 \\
\hline
\end{tabular}

Boala de reflux gastroesofagian a fost diagnosticată la 12/86 copii (14\%), gastrita/gastroduodenita şa 14/86 copii (16\%) (6 dintre aceştia asociau şi boala de reflux gastroesofagian), ulcer duodenal 1 pacient (1\%), parazitoză intestinală 2 pacienţi $(2 \%)$, limfadenita mezenterică 3 copii $(3,5 \%)$, boala celiacă 1 pacient (1\%), colita ucerativă 2 pacienţi $(2 \%)$. Doi dintre pacienţii diagnosticaţi cu boală de reflux gastroesofagian prezentau hernie hiatală. Infecţia cu Helicobacter pylori a fost dovedită în cazul unui singur pacient cu gastrită (antigen fecal pozitiv). În Tabelul 3 sunt trecute tulburările funcţionale gastrointestinale diagnosticate la pacienţii care s-au prezentat pentru dureri abdominale şi numărul acestora.

TABEL 3. Tulburări funcționale gastrointestinale

\begin{tabular}{|l|c|}
\hline Diagnostic & $\begin{array}{c}\text { Număr pacienți (\% din totalul } \\
\text { pacienților studiați) }\end{array}$ \\
\hline Dispepsia funcțională & $17(20 \%)$ \\
\hline Sindromul intestinului iritabil & $9(10,5 \%)$ \\
\hline Migrena abdominală & $4(5 \%)$ \\
\hline $\begin{array}{l}\text { Durere abdominală funcțională } \\
\text { nespecificată }\end{array}$ & $20(23 \%)$ \\
\hline Constipație funcțională & $7(8 \%)$ \\
\hline
\end{tabular}

Au fost 10 pacienţi cu dispepsie funcţională în cazul cărora subtipul a fost precizat ( 5 copii cu sindrom de disconfort postprandial şi $5 \mathrm{cu}$ sindrom de durere abdominală epigastrică). Dintre pacienţii cu sindro- mul intestinului iritabil, 2 aveau subtipul manifestat predominant cu constipaţie, 4 cu diaree, 1 mixt, şi în cazul a doi dintre pacienţi subtipul nu a fost specificat.

\section{Investigații paraclinice}

Hemoleucograma a fost efectuată la $81 / 86$ pacienţi (94\%), parametri sindromului inflamator (VSH, PCR) la 54/86 copii (63\%), transaminazele la 82/86 pacienţi (95\%), glicemia şi amilazemia la câte $24 / 86$ copii (24\%). S-au decelat valori patologice după cum urmează: hemoleucograma 5/81 pacienţi (6\%); parametrii sindromului inflamator $15 / 54$ copii (28\%); transaminazele $9 / 82$ pacienţi (11\%).

În Tabelul 4 sunt redate câteva dintre investigațiile care s-au efectuat la pacienţii studiaţi şi numărul pacienţilor la care s-au decelat modificări sugestive pentru diagnosticul final.

\section{DISCUȚII}

Studiul şi-a propus evaluarea cauzelor durerii abdominale cronice sau recurente la copiii care se prezintă în secţia noastră şi a datelor clinice şi paraclinice care au fost utilizate pentru stabilirea diagnosticului.

Semnele sau simptomele de alarmă au fost prezente la puţin peste jumătate dintre pacienţii care au 
TABEL 4. Investigații paraclinice efectuate la lotul de studiu

\begin{tabular}{|l|c|c|}
\hline Examinare paraclinică & $\begin{array}{c}\text { Număr } \\
\text { pacienți la care } \\
\text { s-a efectuat } \\
(\%)\end{array}$ & $\begin{array}{c}\text { Număr pacienți la care s-au decelat } \\
\text { modificări patologice sugestive pentru } \\
\text { diagnosticul final (\% pacienți la care } \\
\text { s-au decelat modificări, din numărul de } \\
\text { pacienți la catre s-a efectuat investigația) }\end{array}$ \\
\hline Examen coproparazitologic & $10(12 \%)$ & $2(20 \%)$ \\
\hline Calprotectina fecală & $5(6 \%)$ & $3(60 \%)$ \\
\hline Antigene fecale Helicobacter pylori & $9(10 \%)$ & $1(11 \%)$ \\
\hline Anticorpi antitransglutaminază tisulară (IgA) & $6(7 \%)$ & $1(17 \%)$ \\
\hline Ecografie abdominală & $69(80 \%)$ & $5(7 \%)$ \\
\hline Endoscopie digestivă superioară & $21(24 \%)$ & $18(86 \%)$ \\
\hline Colonoscopie & $4(5 \%)$ & $3(75 \%)$ \\
\hline $\begin{array}{l}\text { Impedanța electrică intraluminală/ } \\
\text { pHmetrie esofagiană }\end{array}$ & $1(1 \%)$ & $1(100 \%)$ \\
\hline
\end{tabular}

fost diagnosticaţi cu patologie organică (55\%), dar, în acelaşi timp, au fost descrise şi în cazul a 37\% dintre copiii diagnosticaţi cu boli funcţionale digestive. Tolone şi colaboratorii decelează, de asemenea, o cauză organică la mai mult de jumătate dintre pacienţii investigaţi pentru durere abdominală cronică sau recurentă, dar fără semne de alarmă (17). Gijsbers şi colaboratorii (18) au raportat rezultate similare în ceea ce priveşte patologia organică (prezenţa semnelor de alarmă la 54\% dintre copiii diagnosticaţi cu afecţiuni organice) şi chiar procente mai mari la pacienţii cu patologie funcţională (59\%). Concluzia studiului lui Gijsbers şi colaboratorii a fost că prezenţa semnelor de alarmă nu face diferenţa între o patologie organică şi una funcţională (18). Autorii remarcă, de exemplu, că prezenţa hemoragiei digestive inferioare, datorată unor fisuri anale, nu este neobişnuită în contextul constipaţiei funcţionale (18).

Deşi se recomandă $(9,16)$ determinarea calprotectinei fecale şi a anticorpilor antitransglutaminază tisulară în evaluarea pacienţilor cu durere abdominală cronică/recurentă, aceste investigaţii s-au efectuat la un număr foarte mic de pacienţi. Prevalenţa bolii celiace este în creştere, iar semnele şi simptomele cu care se prezintă pacienţii diferă de cele din descrierea clasică a bolii $(19,20)$. Khatib şi colaboratorii raportează durerea abdominală recurentă la 53\% dintre pacienţii diagnosticaţi cu boală celiacă (19). Kansu şi colaboratorii (5) remarcă asocierea bolii celiace la pacienţi diagnosticaţi cu sindromul intestinului iritabil sau dispepsie funcţională. Pe de altă parte, Turco şi colaboratorii raportează o prevalenţă mai mare a patologiei funcţionale gastrointestinale la pacienţi cu boală celiacă care aveau de un an regim fără gluten, faţă de copiii sănătoşi (6).

Devanarayana şi colaboratorii observă că majoritatea studiilor privind durerea abdominală cronică sau recurentă au fost efectuate în centre secundare sau terţiare (3). Aici, pacienţii sunt selectaţi şi proba- bilitatea ca ei să fie diagnosticaţi cu o patologie organică este mai mare. Gijsbers şi colaboratorii arată că investigaţiile mai amănunţite cresc probabilitatea de a găsi un substrat organic al simptomelor $(18,21)$. În studiul nostru, au fost diagnosticaţi cu o patologie organică 34\% dintre pacienţii care s-au prezentat pentru durere abdominală, un număr mai mic faţă de cel raportat de Størdal şi colaboratorii (45\%) (4), dar mai mare faţă de cel raportat de Devanarayana şi colaboratorii $(24 \%)$ (2). Situaţia diferă foarte mult în cabinetele de medicină primară. Spee şi colaboratorii afirmă că, la aproape $90 \%$ dintre copiii cu vârste între 4 şi 17 ani care s-au prezentat pentru durere abdominală, nu s-a ridicat suspiciunea unei cauze organice (22).

Ecografia abdominală a decelat o cauză care să explice simptomele în puţine cazuri. A fost, totuşi, o investigaţie care s-a indicat într-un număr foarte mare de cazuri. Faptul că este o investigaţie noninvazivă o face uşor de acceptat atât de către copii, cât şi de către părinţi, cu toate că valoarea ei în diagnosticul cauzei durerii abdominale recurente/cronice de cauză digestivă este mică, fapt cunoscut de mult timp (23).

Endoscopia digestivă superioară a fost indicată în studiul nostru la aproape un sfert dintre pacienţi, spre deosebire de studiul publicat recent de Adeniyi şi colaboratorii, care au efectuat această investigaţie la peste $76 \%$ dintre pacienţii evaluaţi pentru durere abdominală (24). Wahid şi colaboratorii raportează date dintr-un centru regional în care s-au efectuat proceduri endoscopice la $17 \%$ dintre copiii evaluaţi, pledând pentru utilizarea cu discernământ a acestor proceduri invazive (25).

Limitele studiului sunt date de numărul relativ mic de pacienţi şi de caracterul său retrospectiv. De asemenea, rezultatele ar putea fi influenţate de faptul că în clinica noastră se efectuează endoscopie digestivă superioară şi inferioară, respectiv impedanţă electrică intraluminală, manometrie esofagiană şi 
anorectală, pacienţii fiind îndrumaţi de multe ori de medici de familie sau specialişti în pediatrie după ce alte investigaţii, mai puţin invazive, s-au efectuat deja. Nu au fost pacienţi la care să găsim asociate în diagnostic afecţiuni organice şi funcţionale.

\section{CONCLUZII}

Caracteristicile clinice ale durerii abdominale şi asocierea semnelor sau simptomelor de alarmă nu

\section{BIBLIOGRAFIE}

1. Apley J, Naish N. Recurrent abdominal pains: a field survey of 1,000 school children. Arch Dis Child. 1958;33(168):165-170.

2. Devanarayana NM, de Silva DG, de Silva HJ. Recurrent abdominal pain syndrome in a cohort of Sri Lankan children and adolescents. J Trop Pediatr. 2008 Jun;54(3):178-83.

3. Devanarayana NM, Rajindrajith S, De Silva HJ. Recurrent abdominal pain in children. Indian Pediatr. 2009 May;46(5):389-99.

4. Størdal K, Nygaard EA, Bentsen B. Organic abnormalities in recurrent abdominal pain in children. Acta Paediatr. 2001 Jun; 90(6):638-42.

5. Kansu A, Kuloğlu Z, Demir A, Yaman A; Turkish Celiac Study Group. Yield of coeliac screening in abdominal pain-associated functional gastrointestinal system disorders. J Paediatr Child Health. 2015 Nov; 51(11):1066-70.

6. Turco R, Boccia G, Miele E, Giannetti E, Buonavolontà R, Quitadamo $P$, Auricchio R, Staiano A. The association of coeliac disease in childhood with functional gastrointestinal disorders: a prospective study in patients fulfilling Rome III criteria. Aliment Pharmacol Ther. 2011 Oct;34(7):783-9.

7. Saps M, Adams P, Bonilla S, Nichols-Vinueza D. Abdominal pain and functional gastrointestinal disorders in children with celiac disease. J Pediatr. 2013 Mar;162(3):505-9.

8. Langshaw AH, Rosen JM, Pensabene L, Borrelli O, Salvatore S, Thapar N, Concolino D, Saps M. Overlap between functional abdominal pain disorders and organic diseases in children. Rev Gastroenterol Mex. 2018 Jul-Sep;83(3):268-274.

9. Reust CE, Williams A. Recurrent Abdominal Pain in Children. Am Fam Physician. 2018 Jun 15;97(12):785-793.

10. Smith J, Fox SM. Pediatric Abdominal Pain: An Emergency Medicine Perspective. Emerg Med Clin North Am. 2016 May;34(2):341-61.

11. Magnúsdóttir MB, Róbertsson V, porgrímsson $S$, Rósmundsson $P$, Agnarsson Ú, Haraldsson Á. Abdominal pain is a common and recurring problem in paediatric emergency departments. Acta Paediatr. 2019 Oct;108(10):1905-1910.

12. Hyams JS, Di Lorenzo C, Saps M, Shulman RJ, Staiano A, van Tilburg M. Functional Disorders: Children and Adolescents. Gastroenterology. 2016 Feb 15:S0016-5085(16)00181-5.

13. Benninga MA, Faure C, Hyman PE, St James Roberts I, Schechter NL, Nurko S. Childhood Functional Gastrointestinal Disorders: Neonate/Toddler. Gastroenterology. 2016 Feb 15:S00165085(16)00182-7.

14. Korterink JJ, Diederen K, Benninga MA, Tabbers MM. Epidemiology of pediatric functional abdominal pain disorders: a meta-analysis. PLoS One. 2015 May 20;10(5):e0126982. sunt suficiente pentru a diferenţia o patologie organică digestivă de una funcţională. Multe dintre investigaţiile paraclinice efectuate la pacienţii cu dureri abdominale recurente/cronice de cauză digestivă nu sunt utile pentru stabilirea cauzei durerii abdominale.

Conflict of interest: none declared Financial support: none declared

15. Bouzios I, Chouliaras G, Chrousos GP, Roma E, Gemou-Engesaeth V. Functional gastrointestinal disorders in Greek Children based on ROME III criteria: identifying the child at risk. Neurogastroenterol Motil. 2017 Mar;29(3).

16. Korterink J, Devanarayana NM, Rajindrajith S, Vlieger A, Benninga MA. Childhood functional abdominal pain: mechanisms and management. Nat Rev Gastroenterol Hepatol. 2015 Mar; 12(3):159-71.

17. Tolone C, Pellino V, Piccirillo M, Letizia M, Belfiore I, Tolone S. Recurrent abdominal pain in children: underlying pathologies in the absence of "alarm" symptoms. Minerva Pediatr. 2017 Aug; 69(4):239-244.

18. Gijsbers CF, Benninga MA, Schweizer JJ, Kneepkens CM, Vergouwe Y, Büller HA. Validation of the Rome III criteria and alarm symptoms for recurrent abdominal pain in children. J Pediatr Gastroenterol Nutr. 2014 Jun;58(6):779-85.

19. Khatib M, Baker RD, Ly EK, Kozielski R, Baker SS. Presenting Pattern of Pediatric Celiac Disease. J Pediatr Gastroenterol Nutr. 2016 Jan;62(1):60-3.

20. Rosén A, Sandström O, Carlsson A, Högberg L, Olén O, Stenlund H, Ivarsson A. Usefulness of symptoms to screen for celiac disease. Pediatrics. 2014 Feb;133(2):211-8.

21. Gijsbers CF, Kneepkens CM, Schweizer JJ, Benninga MA, Büller HA. Recurrent abdominal pain in 200 children: somatic causes and diagnostic criteria. Acta Paediatr. 2011 Nov;100(11):e208-14.

22. Spee LA, Lisman-Van Leeuwen Y, Benninga MA, Bierma-Zeinstra SM, Berger MY. Prevalence, characteristics, and management of childhood functional abdominal pain in general practice. Scand $J$ Prim Health Care. 2013 Dec;31(4):197-202. .

23. Yip WC, Ho TF, Yip YY, Chan KY. Value of abdominal sonography in the assessment of children with abdominal pain. J Clin Ultrasound. 1998 Oct;26(8):397-400.

24. Adeniyi OF, Odeghe EA, Lawal MA, Olowu AO, Ademuyiwa A. Recurrent abdominal pain and upper gastrointestinal endoscopy findings in children and adolescents presenting at the Lagos University Teaching Hospital. PLoS One. 2019 May 23; 14(5):e0216394.

25. Wahid AM, Devarajan K, Ross A, Zilbauer M, Heuschkel R. Paediatric gastrointestinal endoscopy: a qualitative study. Eur J Gastroenterol Hepatol. 2016 Jan;28(1):25-9. 